\title{
A potential role of activated NF- $K B$ in the pathogenesis of euthyroid sick syndrome
}

\author{
Takashi Nagaya, ${ }^{1}$ Miyuki Fujieda, ${ }^{1}$ Goro Otsuka, ${ }^{1}$ Jian-Ping Yang, ${ }^{2}$ \\ Takashi Okamoto, ${ }^{2}$ and Hisao Seo ${ }^{1}$ \\ ${ }^{1}$ Department of Endocrinology and Metabolism, Division of Molecular and Cellular Adaptation, \\ Research Institute of Environmental Medicine, Nagoya University, Nagoya, Japan \\ ${ }^{2}$ Department of Molecular Genetics, Research Institute of Molecular Medicine, \\ Nagoya City University School of Medicine, Nagoya, Japan \\ Address correspondence to: Takashi Nagaya, Department of Endocrinology and Metabolism, \\ Division of Molecular and Cellular Adaptation, Research Institute of Environmental Medicine, Nagoya University, \\ Nagoya 464-8601, Japan. Phone: 81-52-789-3867; Fax: 81-52-789-3891; E-mail: tnagaya@riem.nagoya-u.ac.jp.
}

Received for publication July 6, 1999, and accepted in revised form June 19, 2000.

Euthyroid sick syndrome, characterized by low serum 3,5,3'-triiodothyronine $\left(\mathrm{T}_{3}\right)$ with normal Lthyroxine levels, is associated with a wide variety of disorders including sepsis, malignancy, and AIDS. The degree of low $\mathrm{T}_{3}$ in circulation has been shown to correlate with the severity of the underlying disorders and with the prognosis. Elevated TNF- $\alpha$ levels, which accompany severe illness, are associated with decreased activity of type I $5^{\prime}$-deiodinase (5'-DI) in liver, leading us to speculate that high levels of this factor contribute to euthyroid sick syndrome. Here we demonstrate that the activation of NF- $\mathrm{KB}$ by TNF- $\alpha$ interferes with thyroid-hormone action as demonstrated by impairment of $\mathrm{T}_{3}$-dependent induction of 5 '-DI gene expression in HepG2 cells. Inhibition of NF$\kappa \mathrm{B}$ action by a dominant-negative NF- $\mathrm{\kappa B}$ reversed this effect and allowed $\mathrm{T}_{3}$ induction of $5^{\prime}$-DI. Furthermore, we show that an inhibitor of NF- $\mathrm{KB}$ activation, clarithromycin (CAM), can inhibit TNF- $\alpha$-induced activation of NF- $\kappa B$ and restore $T_{3}$-dependent induction of $5^{\prime}$-DI mRNA and enzyme activity. These results suggest that NF- $\kappa B$ activation by TNF- $\alpha$ is involved in the pathogenesis of euthyroid sick syndrome and that CAM could help prevent a decrease in serum $\mathrm{T}_{3}$ levels and thus ameliorate euthyroid sick syndrome.

J. Clin. Invest. 106:393-402 (2000).

\section{Introduction}

Thyroid hormone is one of the critical hormones in mammals and plays an indispensable role in development as well as in lipid and carbohydrate metabolism and energy generation. The thyroid gland secretes mainly L-thyroxine $\left(\mathrm{T}_{4}\right)$ into the circulation where it is converted to 3,5,3' -triiodothyronine $\left(\mathrm{T}_{3}\right)$ in liver and kidney. Most of the serum $\mathrm{T}_{3}$ is derived from this conversion, which is catalyzed by type I $5^{\prime}$-deiodinase $\left(5^{\prime}\right.$ DI). Expression of the $5^{\prime}$-DI gene is upregulated through liganded thyroid hormone receptor (TR), which binds to a thyroid-hormone responsive element (TRE) in the promoter region of the $5^{\prime}$-DI gene (1).

Euthyroid sick syndrome $(2,3)$, also called low- $\mathrm{T}_{3}$ syndrome or nonthyroidal illness, is characterized by low serum $\mathrm{T}_{3}$ levels. This syndrome is usually associated with the terminal stage of sepsis, malignancy, AIDS, myocardial infarction, and starvation (4). With increasing severity of illness, serum $\mathrm{T}_{4}$ levels are also decreased (4). The prognosis of the underlying disease is correlated with the degree of low $\mathrm{T}_{3}(5,6)$ and with that of low $\mathrm{T}_{4}(7)$. The changes in serum $\mathrm{T}_{4}$ levels in euthyroid sick syndrome have been attributed to a decreased $\mathrm{T}_{4}$ production rate (8), increased metabolic clearance of $\mathrm{T}_{4}$ from serum (9), and diminished hypothalamic and pituitary function (10). As for low serum
$\mathrm{T}_{3}$ levels in this syndrome, one important cause is decreased conversion of $\mathrm{T}_{4}$ to $\mathrm{T}_{3}(8)$ due to decreased 5 '-DI activity in the liver (11).

Although there are conflicting data (12-15), TNF- $\alpha$ is suggested to be one of the candidates for causing euthyroid sick syndrome. The relevance of TNF- $\alpha$ in this syndrome is supported by the following observations: (a) injection of TNF- $\alpha$ into healthy volunteers resulted in reduced serum $\mathrm{T}_{3}$ levels (16); (b) serum $\mathrm{T}_{3}$ levels were lower in nursing home patients with detectable serum TNF- $\alpha$ than those with undetectable levels (17); and (c) the single injection of TNF- $\alpha$ into rats resulted in decreased serum $T_{3}$ levels with repressed $5^{\prime}$-DI activity in liver (18). We thus focused this study on how TNF- $\alpha$ causes euthyroid sick syndrome.

TNF- $\alpha$ exerts its biological activities through the activation of the transcription factor NF- $\kappa \mathrm{B}$. Upon stimulation of cells with TNF- $\alpha, N F-\kappa B$ is translocated from the cytoplasm to the nucleus through the signalinduced degradation of its inhibitory proteins, IKBs (19). NF- $\kappa B$ plays a pivotal role in immune and inflammatory responses by controlling gene expression of a number of cytokines. It was reported that NF- $\kappa \mathrm{B}$ was induced in PBMCs of septic patients (20). Since 5'-DI gene expression is upregulated by $\mathrm{T}_{3}$-TR signaling, we speculated that the $\mathrm{T}_{3}$-dependent induction of $5^{\prime}$-DI 
might be interfered with by the TNF- $\alpha$-mediated NF$\kappa \mathrm{B}$ activation, culminating in euthyroid sick syndrome.

Since liver is the major site of $\mathrm{T}_{4}$ to $\mathrm{T}_{3}$ conversion, we examined the effect of activated NF- $\mathrm{KB}$ on $\mathrm{T}_{3}$-dependent $5^{\prime}$-DI induction in a human hepatoma cell line, HepG2, which retains differentiated function (21). Here we demonstrate that activation of NF- $\kappa \mathrm{B}$ by TNF$\alpha$ impairs $\mathrm{T}_{3}$-dependent induction of $5^{\prime}$-DI mRNA and enzyme activity. Furthermore, we found that the macrolide antibiotic clarithromycin (CAM) inhibited the TNF- $\alpha$-induced NF- $\kappa$ B activation and restored the responses of $5^{\prime}$-DI mRNA and enzyme activity to $T_{3}$.

\section{Methods}

Plasmids. The constructions of plasmids expressing $\mathrm{TR} \beta$, p50 subunit of $\mathrm{NF}-\kappa \mathrm{B}, \mathrm{p} 65$ subunit of $\mathrm{NF}-\kappa \mathrm{B}$, a dominant-negative form of p65 (p65 DN), and CREB (c-AMP responsive element binding protein) binding protein $(\mathrm{CBP})$, and the luciferase reporter genes (3xPal TK Luc, TSH- $\alpha$ Luc, and NF- $\kappa$ B pGL3 pro Luc) were described previously (22-27). For the yeast twohybrid system, cDNAs for full-length human TR $\beta$ or I $\mathrm{B} \beta$ were subcloned into the vector expressing Gal4 DNA-binding domain (DBD) (pGBT9) in-frame. Also, full-length RXR $\alpha$ or p65 cDNAs were subcloned into the Gal4 activation domain (pACT2) inframe. For the mammalian two-hybrid system, the cDNA for the full-length human TR $\beta$ was subcloned into the vector expressing Gal4 DBD (pM) in-frame. Also, full-length p65 cDNA was subcloned into the VP16 activation domain (pVP16) in-frame. The promoter region $(-716$ to +24$)$ of the human 5 '-DI gene (1) was amplified by PCR using human genomic DNA as a template. After verification of its sequence, it was subcloned into pGL3 basic Luc plasmid (Promega, Madison, Wisconsin, USA) to construct the human $5^{\prime}$-DI luciferase reporter gene ( $5^{\prime}$-DI Luc). The human type I $5^{\prime}$-DI cDNA fragment (nucleotide sequences 163 to 537) (28) for hybridization was also amplified by RT-PCR using total RNA from HepG2 cells and cloned into pGEM-T vector (Promega). The probes for GAPDH, malic enzyme (ME) and spot 14, were reported previously $(29,30)$.

RNA extraction and Northern blot analysis. Cells from the human hepatoma cell line HepG2 were obtained from ATCC (American Type Culture Collection, Rockville, Maryland, USA) and cultured in DMEM (Nissui, Tokyo, Japan) containing 10\% FBS, $100 \mathrm{U} / \mathrm{mL}$ penicillin, and $100 \mu \mathrm{g} / \mathrm{mL}$ streptomycin. At 70\% confluence, the cells were maintained in DMEM with 5\% charcoal-stripped FBS. After addition of TNF- $\alpha$ (100 $\mathrm{U} / \mathrm{mL})$ and/or $\mathrm{T}_{3}(100 \mathrm{nM})$, the cells were harvested 24 hours later. Total RNA was extracted by the acid guanidine phenol/chloroform method (31). Ten micrograms of total RNA was separated by $0.8 \%$ agarose-gel electrophoresis, blotted on a nitrocellulose membrane (Gene Screen Plus; NEN Life Science Products, Boston, Massachusetts, USA), and hybridized with a ${ }^{32} \mathrm{P}-$ labeled cDNA probe for 5'-DI or GAPDH. The condi- tions for hybridization and for washing were described previously (29). To determine the amount of each mRNA, the hybridized membrane was exposed to the imaging plate, and the radioactivity of a specific band was measured by using Fujix Bioimage Analyzer (BAS 2000; Fuji Photo Film, Tokyo, Japan) before autoradiography. The radioactivity of the 5'-DI mRNA band was adjusted by that of GAPDH, and the mRNA level was expressed as an arbitrary unit. Then, autoradiography was carried out by exposing the hybridized membrane to Kodak X-AR film (Eastman Kodak, Rochester, New York, USA). The same membrane was rehybridized with cDNAs for ME and spot 14 .

Assay of 5'-DI activity. HepG2 cells were cultured in sixwell plates (Falcon 3046 Multiwell tissue culture plate; Becton Dickinson Labware, Franklin Lakes, New Jersey, USA) with DMEM containing 10\% FBS. Near confluence, the cells were washed with serum-free DMEM and then cultured in DMEM containing 5\% charcoal-stripped serum in the absence or presence of $100 \mathrm{nM} \mathrm{T}_{3}$, TNF- $\alpha$ $(100 \mathrm{U} / \mathrm{mL})$, and/or CAM $\left(10^{-4} \mathrm{M}\right)$ for 24 hours. Then, the cells were harvested and homogenized in a buffer (100 $\mathrm{mM}$ potassium phosphate, $\mathrm{pH}$ 7.0, $1 \mathrm{mM}$ EDTA, $0.5 \mathrm{mM}$ DTT). Homogenates were centrifuged at $13,000 \mathrm{~g}$ for 15 minutes. The supernatant was collected and the protein concentration was determined by a Bio-Rad protein assay kit (Bio-Rad Laboratories, Hercules, California, USA).

The enzyme activity of 5 -DI was assayed by the method described (32), with a minor modification. In brief, the supernatant was incubated at $37^{\circ} \mathrm{C}$ for $15 \mathrm{~min}$ utes in a total volume of $100 \mu \mathrm{L}$ of buffer containing 0.5 $\mu \mathrm{M}{ }^{125} \mathrm{I}-\mathrm{rT} 3$ (NEN Life Science Products), which was purified by column chromatography using LH-20 (Pharmacia Biotech AB, Uppsala, Sweden). The reaction was terminated by the addition of $100 \mu \mathrm{L}$ of $2 \%$ BSA and $800 \mu \mathrm{L}$ of $10 \%$ trichloroacetic acid and centrifuged at $13,000 \mathrm{~g}$ for 15 minutes. The supernatant was applied to a Dowex-50 (Bio-Rad Laboratories) ion-exchange resin column (bed volume: $1 \mathrm{~mL}$ ) and eluted with $2 \mathrm{~mL}$ of $10 \%$ acetic acid. Radioactivity of the eluate was counted with a $\gamma$-counter (ARC-1000M; Aloka, Tokyo, Japan). The radioactivity released from ${ }^{125} \mathrm{I}$-rT3 was adjusted to be less than $20 \%$ of total input. The enzyme activity was corrected by subtracting iodide released in tissue-free tubes, which was less than $2 \%$ of the total count. The $5^{\prime}$-DI activity was expressed as $\mathrm{pmol} \mathrm{I}^{-} / \mathrm{mg}$ protein $/ \mathrm{min}$. The data were expressed as mean plus or minus SD $(n=6)$.

Cell treatment and preparation of nuclear extract. HepG2 cells were maintained in DMEM containing $5 \%$ charcoal-stripped FBS for at least 16 hours. After 1 hour preincubation with CAM, TNF- $\alpha$ was added, and the cells were incubated for another 1 hour. The cells were then harvested and subjected to preparation of nuclear extract. The method to prepare the extract was described previously (33).

Electrophoretic mobility shift assay. The method for electrophoretic mobility-shift assay (EMSA) and the sequences of oligonucleotides used (NF- $\mathrm{KB}$ oligonucleotides and TRE-Lap) were reported previously (26, 
a

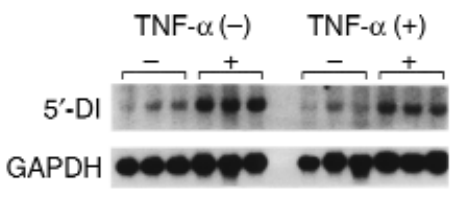

b

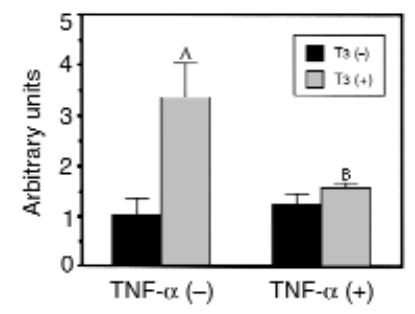

c

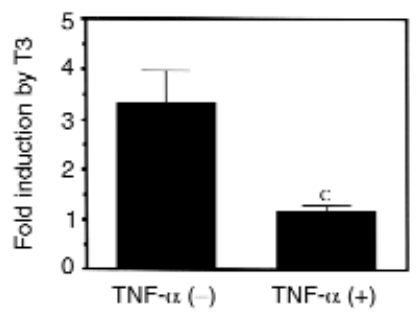

Figure 1

TNF- $\alpha$ attenuates $T_{3}$-dependent induction of type I 5'-DI gene. (a) HepG2 cells were treated with $\mathrm{T}_{3}(100 \mathrm{nM})$ and/or TNF- $\alpha(100 \mathrm{U} / \mathrm{mL}$ ) for 24 hours. The levels of $5^{\prime}$-DI and GAPDH mRNAs were determined by Northern blot analysis. (b) The radioactivity of the hybridized bands was measured by using Fujix Bioimage Analyzer BAS 2000. The levels of 5'-DI/GAPDH mRNA (in arbitrary units) were expressed as mean \pm SD. (c) The fold induction of 5'-DI/GAPDH mRNA by $T_{3}$ was depicted. ${ }^{A} P<0.0001$ vs. $T_{3}(-) ;{ }^{B} P<0.0001, T_{3}(+), T_{N F}-\alpha(-)$ vs. $T_{3}$ $(+)$, TNF- $\alpha(+)$ in $\mathbf{b} ;{ }^{C} P<0.0001$ vs. TNF- $\alpha(-)$ in $\mathbf{c}$.

34). For the supershift analyses, the antisera against each subunit of NF- $\mathrm{KB}$ (anti-p50, p52, p65, c-Rel, RelB, and $\mathrm{Bcl}-3$ antibodies; Santa Cruz Biotechnology, Santa Cruz, California, USA) were added after formation of protein-DNA complex and further incubated on ice for 1 hour. The reaction mixtures were applied in 5\% polyacrylamide gel with $2.5 \%$ glycerol and $0.5 \times \mathrm{TBE}(45 \mathrm{mM}$ Tris-borate, $1 \mathrm{mM}$ EDTA). In vitro translated TR $\beta$, RXR $\alpha$, or p65 of NF- $\mathrm{kB}$ were synthesized using TNTcoupled reticulocyte lysate system (Promega), according to the protocol from the supplier.

Transient-expression assays. Human choriocarcinoma cell line JEG-3 cells were grown in Opti-MEM (Life Technologies, Grand Island, New York, USA) containing $2 \%$ FBS, penicillin, and streptomycin. HepG2 cells were grown in DMEM containing 10\% FBS. The cells were plated in 12-well dishes 16 hours before transfection and were transfected with the calcium phosphate method (35). A reporter plasmid $(1 \mu \mathrm{g})$ was transfected together with TR-expressing plasmid (100 ng), either with the plasmid expressing p50, p65, or p65 DN. The total amount of plasmid was maintained constant in each transfection by the addition of the control plasmid without a cDNA insert. To monitor the transfection efficiency, $\beta$-galactosidase expression plasmid ( $\mathrm{pEBV} \beta$ gal: 50 ng per well) was used. After 4 hours' exposure to the calcium phosphate-DNA precipitate, culture medium containing charcoal-stripped FBS was added, with or without $100 \mathrm{nM} \mathrm{T}_{3}$. DMEM with $5 \%$ stripped FBS for HepG2 cells and Opti-MEM with 2\% stripped FBS for JEG-3 cells were used. Cells were harvested after 24 hours and luciferase activity (36) was measured using a luminometer (LB9501; Berthold, Wildbad, Germany). The $\beta$-galactosidase activity was assayed by using $\beta$ galactosidase Assay Kit (Galacto-Light Plus; Tropix, Bedford, Massachusetts, USA). Luciferase activity was adjusted by $\beta$-galactosidase activity. Transfections were carried out in triplicate and repeated at least three times. The data were expressed as luciferase/ $\beta$-galactosidase activity (arbitrary unit), or fold induction by $\mathrm{T}_{3}$ (using positive TRE-reporter constructs), or percentage of relative luciferase activity by $\mathrm{T}_{3}(\mathrm{TSH}-\alpha \mathrm{Luc})$.
Yeast two-bybrid system. The interaction between TR and p65 was analyzed by yeast two-hybrid system (Matchmaker Two-Hybrid System; Clontech, Palo Alto, California, USA), according to the protocol from the supplier. The PGBT9 plasmid was transformed with pACT2 plasmid into yeast cells (Y187). Trp ${ }^{+}, \mathrm{Leu}^{+}$ colonies were grown in SD medium without tryptophan and leucine, and $\beta$-galactosidase activity in liquid
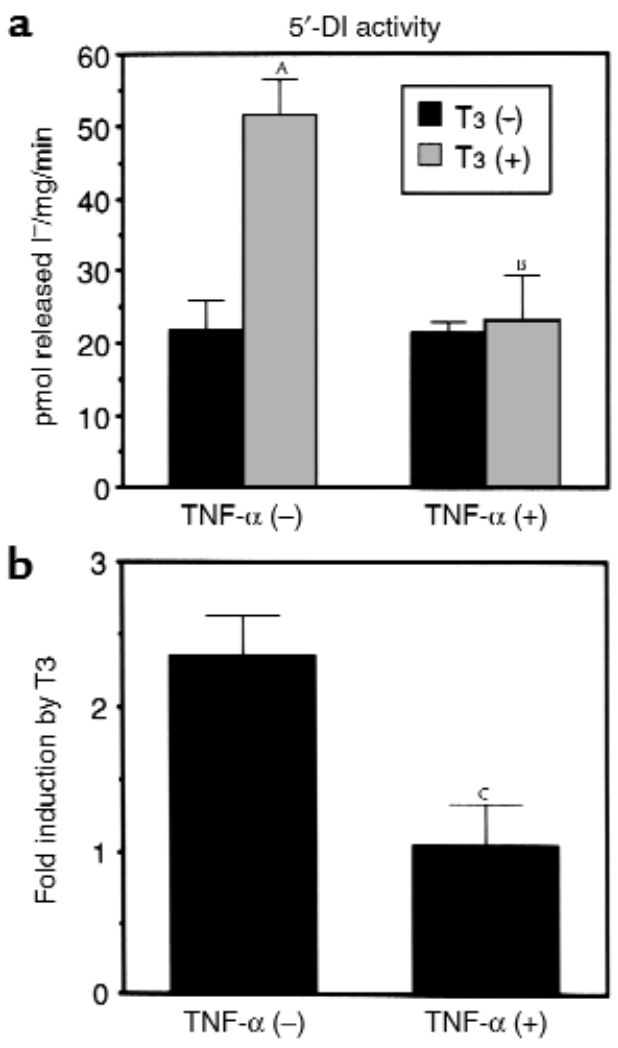

Figure 2

TNF- $\alpha$ decreases $T_{3}$-dependent increase of $5^{\prime}$-DI enzyme activity. (a) HepG2 cells were treated with $T_{3}(100 \mathrm{nM})$ and/orTNF- $\alpha(100 \mathrm{U} / \mathrm{mL})$ for 24 hours. The enzyme activity of $5^{\prime}$-DI in cytosolic extract was expressed as mean $\pm \mathrm{SD}(n=6)$. (b) The fold induction of $5^{\prime}$-DI enzyme activity by $T_{3}$ is depicted. ${ }^{A} P<0.0001$ vs. $T_{3}(-) ;{ }^{B} P<0.0001, T_{3}(+)$, TNF- $\alpha(-)$ vs. $T_{3}(+)$, TNF- $\alpha(+)$ in $\mathbf{a} ;{ }^{C} P<0.0001$ vs. TNF- $\alpha(-)$ in $\mathbf{b}$. 


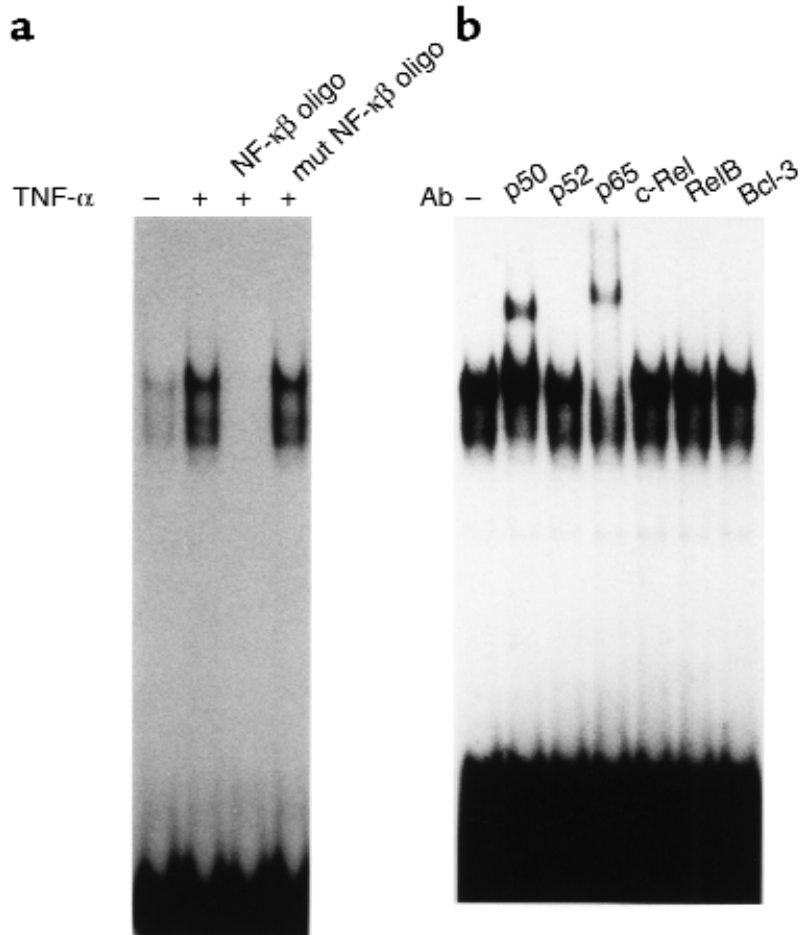

Figure 3

Characterization of activated NF- $\mathrm{KB}$ in HepG2 cells. (a) The activation of NF- $\kappa B$ by TNF- $\alpha$ in HepG 2 cells was studied using EMSA. The nuclear extract was prepared after 1-hour treatment with TNF$\alpha$. (b) Characterization of NF-KB complex by supershift analysis. The antibodies specific to NF-KB subunits were used in EMSA. mut, mutated; oligo, oligonucleotide.

culture was determined using a $\beta$-galactosidase assay kit. $\beta$-galactosidase activity/cell density $\left(\mathrm{OD}_{600}\right)$ was calculated to assess the association of the two proteins.

Mammalian two-hybrid system. The interaction between TR and p65 was also analyzed by the mammalian twohybrid system (Mammalian Matchmaker two-hybrid assay kit; Clontech) according to the protocol from the supplier. Gal4 DBD-TR (pM-TR) and VP16-p65 (pVPp65) were transfected into JEG-3 cells by calcium phosphate method, together with Gal4-responsive luciferase reporter gene ( $p G L u c)$. Twenty-four hours after transfection, luciferase activity was measured to evaluate the association between TR and p65.

Chemicals. Human recombinant TNF- $\alpha\left(2.5 \times 10^{3}\right.$ $\mathrm{U} / \mu \mathrm{g})$ was kindly provided by Asahi Chemical Industry (Tokyo, Japan). CAM was provided by Taisho Pharmaceutical (Tokyo, Japan) and dissolved in DMSO to a final concentration of $10^{-1} \mathrm{M}$ as a stock solution. DMSO was added to adjust the concentration in the experiments using CAM. The maximum concentration of CAM used was $10^{-4} \mathrm{M}$, based on the following observation: the usual dose of CAM is $200-400 \mathrm{mg} /$ day in adults, and the concentration in peripheral blood is approximately $1.0 \mu \mathrm{g} / \mathrm{mL}\left(1.34 \times 10^{-6} \mathrm{M}\right)(37)$. In the experiments using rats and mice, the concentrations of CAM in the liver, lung, and kidney were reported to be 24-84 times higher than that in peripheral blood (38).
Statistical analyses. The data were expressed as mean plus or minus SD. Statistical difference was analyzed by oneway ANOVA with Bonferroni's test in all the experiments.

\section{Results}

Inbibition of $T_{3}$-dependent increase of 5'-DI $m R N A$ and enzyme activity by TNF- $\alpha$. To examine whether TNF- $\alpha$ might be involved in the inhibition of $5^{\prime}$-DI gene expression in the liver, Northern blot analysis was performed using HepG2 cells. As reported previously (1), incubation of HepG2 cells with $\mathrm{T}_{3}$ for 24 hours resulted in an increase in 5'-DI mRNA levels (Figure 1). The $\mathrm{T}_{3}$-dependent increase in the mRNA was 3.3-fold. In the presence of TNF- $\alpha, 5^{\prime}$-DI mRNA levels without $T_{3}$ were not changed. However, the induction of $5^{\prime}$-DI mRNA by $T_{3}$ was attenuated by TNF- $\alpha$ to 1.2 -fold, suggesting that TNF- $\alpha$ impairs $\mathrm{T}_{3}$-dependent induction of 5'-DI mRNA expression.

We next examined whether the changes in the $5^{\prime}$-DI mRNA levels are associated with $5^{\prime}$-DI activity. As shown in Figure 2, the enzyme activity was increased by 2.3 -fold (from $21.8 \pm 4.0$ to $51.3 \pm 6.1$ pmol released
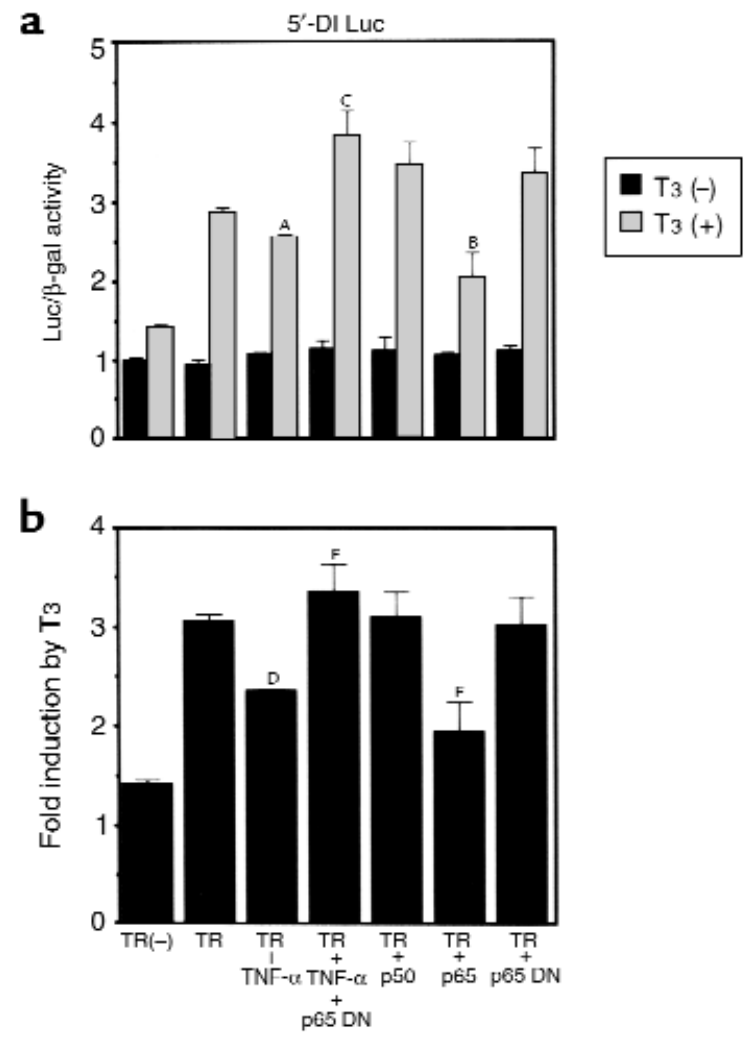

\section{Figure 4}

NF- $K B$ induced by TNF- $\alpha$ inhibits $T_{3}$-dependent induction of $5^{\prime}-D I . T_{3}-$ dependent induction of $5^{\prime}$-DI Luc activity was inhibited by NF-KB induced with TNF- $\alpha$. $T_{3}$-dependent induction of $5^{\prime}$-DI Luc was also inhibited by transfection of the plasmid expressing p65. This inhibition was reversed by transfection of the plasmid expressing p65 DN. (a) The values of Luc/ $\beta$-gal activity with or without $T_{3}$. ${ }^{A} P<0.001$, ${ }^{\mathrm{B}} P<0.0001$ vs. TR, $\mathrm{T}_{3}(+)$; ${ }^{\mathrm{C}} P<0.0001, \mathrm{TR}, \mathrm{T}_{3}(+)$, TNF- $\alpha$ vs. TR, $\mathrm{T}_{3}$ $(+)$, TNF- $\alpha$, p65 DN. (b) Fold induction by $\mathrm{T}_{3} .{ }^{\mathrm{D} P}<0.001$, E $P<0.0001$ vs. TR; ${ }^{F} P<0.0001$, TR + TNF- $\alpha$ vs. TR + TNF- $\alpha+$ p65 DN. 
$\mathrm{I}^{-} / \mathrm{mg} / \mathrm{min}$ ) in the presence of $\mathrm{T}_{3}$. TNF- $\alpha$ treatment did not alter the activity without $T_{3}$, but impaired $T_{3^{-}}$ dependent increase in this enzyme activity. It is thus demonstrated that inhibition of $\mathrm{T}_{3}$-dependent increase in $5^{\prime}$-DI mRNA by TNF- $\alpha$ was associated with concordant change in the enzyme activity.

Inbibition of $\mathrm{T}_{3}$-dependent induction of $5^{\prime}$-DI by activated $N F-\kappa B$. Since TNF- $\alpha$ induces nuclear translocation and DNA binding of transcription factor NF- $\mathrm{NB}$, the activated NF- $\mathrm{KB}$ in HepG2 cells was analyzed by EMSA using a NF- $\kappa B$-binding oligonucleotide as a probe. The nuclear extract of HepG2 cells cultured in the absence of TNF- $\alpha$ showed two faint protein-DNA complexes, and amounts of these complexes were increased after 1-hour treatment of TNF- $\alpha$ (Figure $3 a)$. Binding of the probe was completely displaced by the unlabeled NF-KB-binding oligonucleotide, but not by the mutated oligonucleotide. Supershift analysis using the subunit-specific antibodies to various NF- $\kappa \mathrm{B}$ components revealed that these complexes comprised p65 and p50 (Figure 3b). Other antibodies recognizing p52, c-Rel, RelB, or Bcl-3 did not affect the mobility of the binding complexes. It is thus suggested that effect of TNF- $\alpha$ may be mediated by p65-p50 heterodimer in HepG2 cells.
We next investigated whether activated NF- $\kappa B$ affects $\mathrm{T}_{3}$-dependent induction of the $5^{\prime}$-DI gene. For this purpose, we employed transient transfection analysis in HepG2 cells using luciferase reporter genes driven by the $5^{\prime}$-DI gene promoter (5'-DI Luc). As shown in Figure $4, \mathrm{~T}_{3}$ slightly increased $5^{\prime}$-DI Luc activity in the absence of transfected TR, although the increase was not statistically significant. When the cells were transfected with the plasmid expressing $T R, T_{3}$ induced the expression of $5^{\prime}$-DI Luc by approximately 3.1-fold (Figure $4 \mathrm{~b}$ ). The addition of TNF- $\alpha$ did not alter Luc activity in the absence of $\mathrm{T}_{3}$, with or without cotransfected TR. However, TNF- $\alpha$ decreased $\mathrm{T}_{3}$-dependent activation of $5^{\prime}$-DI Luc to 2.3 -fold in cells also transfected with the TR-expressing plasmid. These results are compatible with those obtained from Northern blot analysis and $5^{\prime}$-DI-enzyme assay (Figure 1 and 2). The effect of TNF- $\alpha$ was considered to be due to the activation of $\mathrm{NF}-\kappa \mathrm{B}$, since cotransfection of the dominant-negative p 65 prevents the effects of TNF- $\alpha$ on $T_{3}$-induced 5 -DI reporter gene expression (TR $+\mathrm{TNF}-\alpha+\mathrm{p} 65 \mathrm{DN})$. Consistent with this finding, the transfection of the plasmid expressing $\mathrm{p} 65$ inhibited $\mathrm{T}_{3}$-dependent activation of the 5'-DI Luc. Since reporter gene assays require cotransfection of TR, the modest inhibitory effect of a

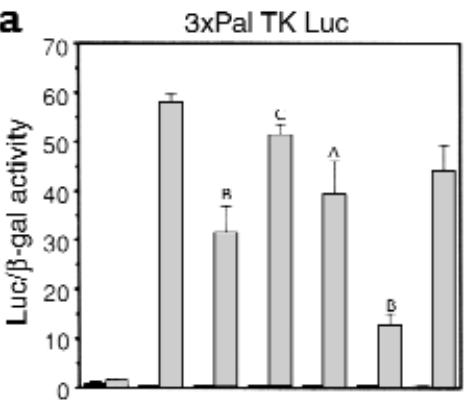

b

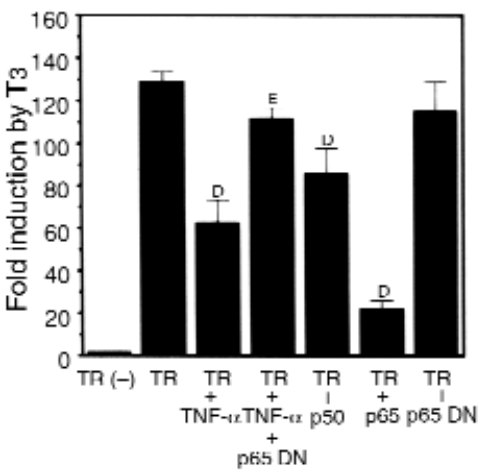

C

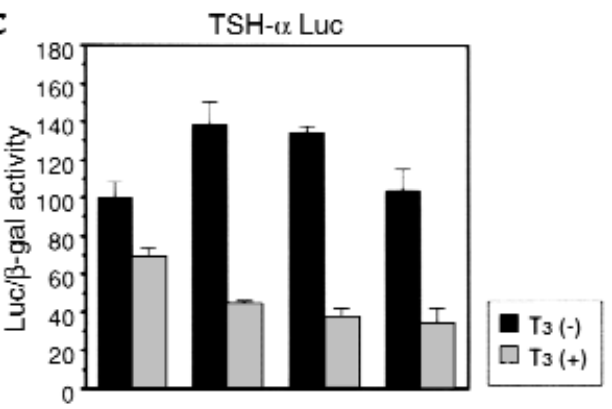

d

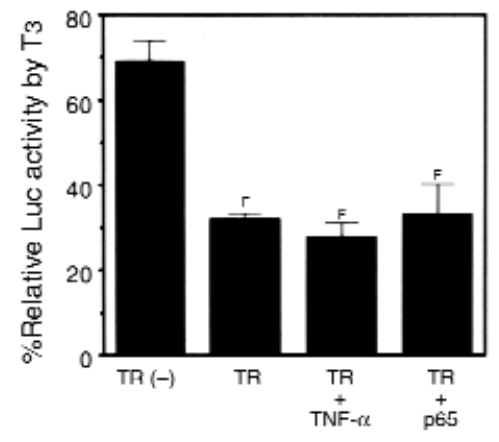

Figure 5

NF-KB induced by TNF- $\alpha$ inhibits reporter-gene expression positively regulated by $T_{3}$ but not the expression of TSH- $\alpha$ Luc, which is negatively regulated by $T_{3}$. (a and $\left.\mathbf{b}\right) T_{3}$-dependent activation of $3 \times P a l$ TK Luc activity was inhibited by NF- $\kappa B$ induced with TNF- $\alpha$. $T_{3}$-dependent activation of $3 \times \mathrm{Pal}$ TK Luc was also inhibited by transfection of the plasmid expressing $\mathrm{p} 65$ and weakly by that expressing $\mathrm{p} 50$. This inhibition was reversed by transfection of $\mathrm{p} 65 \mathrm{DN}$ expressing plasmid. (a) The values of $3 x \mathrm{xPal}$ TK Luc/ $\beta$-gal activity. ${ }^{A} P<0.001,{ }^{B} P<0.0001 \mathrm{vs}$. TR, $T_{3}(+) ;{ }^{C} P<0.0001, T R, T_{3}(+)$, TNF- $\alpha$ vs. TR, $T_{3}(+)$, TNF- $\alpha$, p65 DN. (b) Fold induction by $T_{3}$. $D P<0.001, E P<0.0001, T R+T N F-\alpha v s$. TR + TNF- $\alpha+$ p65 DN. (c and d) JEG-3 cells were transfected with TSH- $\alpha$ Luc gene, and the effect of $\mathrm{T}_{3}$ and/or TNF- $\alpha$ was studied. T3dependent repression of TSH- $\alpha$ Luc gene was not inhibited by NF-KB induced with TNF- $\alpha$. (c) The values of TSH- $\alpha$ Luc/ $\beta$-gal activity. (d) Percentage relative $T_{3}$ Luc activity by $T_{3}$. ${ }^{F} P<0.0001$ vs. $T R(-)$. All the data were expressed as mean \pm SD. 
a

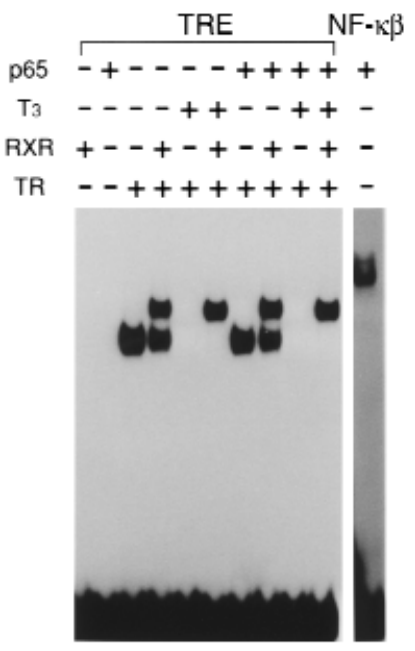

b

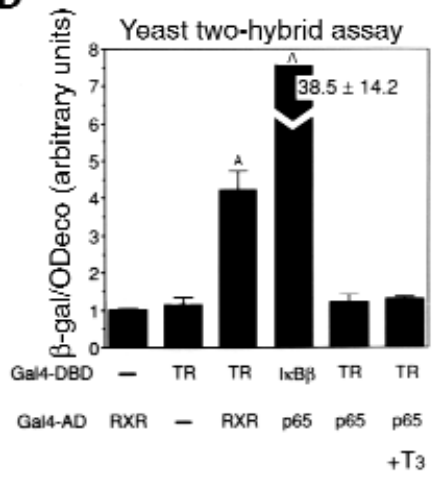

\section{Figure 6}

Lack of association of TR with NF-KB p65 subunit in the presence or absence ofTRE. (a) TR and active form of NF-KB, p65, do not associate on TRE. EMSA using LapTRE revealed that TR formed a homodimer and a heterodimer complex with RXR. However, the presence of p65 did not affect TR binding and did not form a new retarded complex. (b) Protein-protein interaction between TR and $p 65$ does not occur in the yeast two-hybrid system. Association of TR and RXR, or p 65 and IKB $\beta$, is evident. Data were expressed as mean \pm SD from triplicate determinations. ${ }^{A} P<0.0001$ vs. Gal4-DBD-TR, Gal4-AD.
TNF- $\alpha$ in luciferase assays may be explained by excess of target-gene promoter as well as TR. Another possibility is that the TNF- $\alpha$ effect on deiodinase mRNA may be mediated in part by gene sequences not included in the luciferase construct or that the effect might in part be posttranscriptional.

Inhibition of $T_{3}$-dependent induction of $T_{3}$-responsive genes by activated NF- $K B$ is not restricted to $5^{\prime}-D I$ gene. To study whether the inhibitory effect of TNF- $\alpha$ on $T_{3}$-induced gene expression is specific to $5^{\prime}$-DI, changes in mRNA levels of two other $\mathrm{T}_{3}$-responsive genes, $\mathrm{ME}$ and spot 14, were determined in HepG2 cells in the presence of $\mathrm{T}_{3}$ and/or TNF- $\alpha$.

Unfortunately, ME mRNA was not detected in HepG2 cells either in the absence or presence of $\mathrm{T}_{3}$. Furthermore, mRNA levels of spot 14 gene were not affected by $\mathrm{T}_{3}$ (data not shown). Inability to detect ME mRNA in HepG2 cells (39) and unresponsiveness of spot 14 mRNA to $T_{3}$ in the cell line (40) were also reported.

We thus employed a reporter gene harboring a TRE to test whether the effect of TNF- $\alpha$ is specific to $5^{\prime}$-DI gene expression. Transient transfection assays were performed using luciferase reporter genes driven by the optimized TRE ( $3 \mathrm{xPal}$ TK Luc) and by the TSH- $\alpha$ pro- moter (TSH- $\alpha$ Luc). As observed in the reporter gene assay for $5^{\prime}$-DI, cotransfection of TR-expressing plasmid was necessary to demonstrate $T_{3}$-dependent changes in these luciferase activities.

As shown in Figure 5, a and b, the $\mathrm{T}_{3}$-mediated increase of 3xPal TK Luc expression was 129-fold when cotransfected with TR. This $\mathrm{T}_{3}$-dependent induction was dramatically reduced to 62 -fold by TNF- $\alpha$. Moreover, when p65 was overexpressed, even greater inhibition was observed (to 21-fold); p65 DN abolished the effect of TNF- $\alpha$. Overexpression of p50 also reduced the $\mathrm{T}_{3}$-dependent increase of $3 \mathrm{xPal}$ TK Luc activity, although to a lesser extent.

We also examined the effect of TNF- $\alpha$ or p65 overexpression on the expression of TSH- $\alpha$ Luc by transienttransfection assays in JEG-3 choriocarcinoma cells in which TSH- $\alpha$ gene expression is preserved (Figure $5 \mathrm{c}$ ). In this cell line, the presence of functional TNF- $\alpha$ receptor was ascertained by the finding that a 6.6 -fold increase in the expression of the NF- $\mathrm{KB}$-responsive luciferase reporter gene (NF-kB pGL3pro Luc) was induced by TNF- $\alpha$ (data not shown). In addition, TNF$\alpha$ treatment or transfection with p65-expressing plasmid inhibited $\mathrm{T}_{3}$-dependent activation of $3 \mathrm{xPal}$ TK Luc a

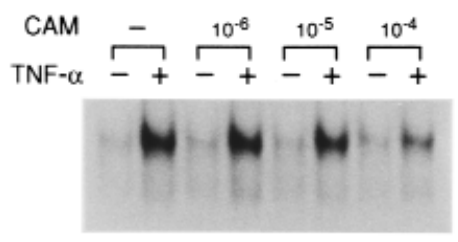

b

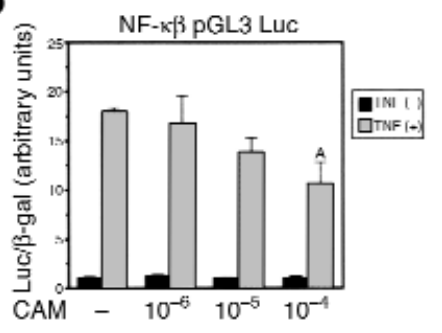

c

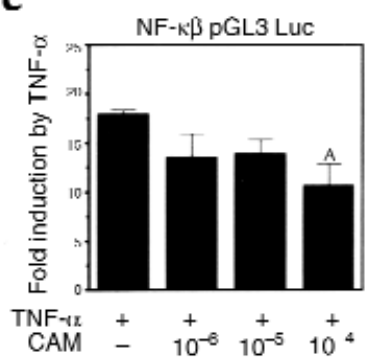

Figure 7

CAM inhibits NF- $\kappa B$ activation. (a) Inhibition of TNF- $\alpha$-induced NF- $K B$ activation by pretreatment with CAM. HepG2 cells were pretreated with CAM for 1 hour at the indicated concentration. After 1 -hour treatment with TNF- $\alpha, N F-K B$ activation in the nuclear extracts was analyzed using EMSA. ( $b$ and $\mathbf{c}$ ) HepG2 cells were transfected with NF-KB pGL3 Luc and treated with TNF- $\alpha$ and CAM for 24 hours. (b) The values of Luc/ $\beta$-gal activity. ${ }^{A} P<0.0001$ vs. TNF- $\alpha(+)$, CAM (-). (c) Fold induction by TNF- $\alpha .{ }^{A} P<0.0001$ vs. TNF- $\alpha(+)$, CAM (-). 
in this cell line, from 220 -fold increase by $\mathrm{T}_{3}$ to 178 -fold and 36-fold, respectively (data not shown). However, $\mathrm{T}_{3}$-dependent repression of TSH- $\alpha$ Luc was not altered by TNF- $\alpha$ or by transfection with p 65 expressing plasmid, suggesting that repression of TSH- $\alpha$ gene expression by $\mathrm{T}_{3}$ was not influenced by the activated NF- $\mathrm{\kappa B}$. These results suggest that activated NF- $\kappa B$ inhibits only the transcription of genes that are positively regulated by $\mathrm{T}_{3}$ (such as $3 \mathrm{xPal}$ TK or $5^{\prime}$-DI), but it does not affect the transcription of genes that are negatively regulated by $\mathrm{T}_{3}$ (i.e., $\mathrm{TSH}-\alpha$ ).

Lack of direct association between TR and $p 65$. To examine whether the inhibition of TR action by the activated NF$\kappa \mathrm{B}$ is due to an association between TR and NF- $\mathrm{\kappa B}$ p65 on a TRE, we used EMSA. Since inhibition of $\mathrm{T}_{3}$-dependent activation by NF- $\kappa \mathrm{B}$ was observed, irrespective of positive TRE structures, an optimized TRE consisting of an everted TRE (TRE-Lap) was used as a probe. As shown in Figure $6 \mathrm{a}, \mathrm{TR} \beta$ bound to this TRE as a homodimer and also as a heterodimer with RXR $\alpha$. In the presence of $\mathrm{T}_{3}$, the homodimer binding, but not the heterodimer, was eliminated. When in vitro-translated $\mathrm{p} 65$ was incubated with TR $\beta$ and/or RXR $\alpha$, no additional complex or decrease in TR binding was observed, even in the presence of $T_{3}$. These results suggest that p65 does not directly associate with the TR on a TRE.
To further investigate whether a direct interaction exists between TR and p65, the yeast two-hybrid system was employed. When Gal4-DBD-TR and Gal4-AD-RXR were cotransformed into yeast cells, $\beta$-galactosidase activity increased, reflecting the association of the two proteins. The strong association of $\mathrm{p} 65$ with $\mathrm{I} \kappa \mathrm{B} \beta$ was also confirmed by this system (Figure 6b). However, the association of TR with p 65 was not detected, irrespective of the absence or the presence of $\mathrm{T}_{3}$. The mammalian two-hybrid system also confirmed that there was no detectable association between TR and p65 (data not shown). These results suggest that the inhibitory effect of NF- $\kappa \mathrm{B}$, especially of p 65 , on TR action is not due to interaction between these two proteins. Lack of interaction between NF- $\kappa B$ and TR raises the possibility that sequestration of the common cofactor such as CBP is the cause of p65-dependent inhibition of TR action. However, overexpression of CBP did not restore TNF$\alpha$-dependent and p65-dependent inhibition of $\mathrm{T}_{3^{-}}$ mediated reporter gene activation using $5^{\prime}$-DI Luc and 3xPal TK Luc (data not shown).

$C A M$ inbibits $N F-\kappa B$ activation and restores $5^{\prime}-D I$ expression. Since $\mathrm{T}_{3}$-dependent increase in $5^{\prime}$-DI mRNA expression was inhibited by TNF- $\alpha$ through activated $\mathrm{NF}-\kappa \mathrm{B}$, we speculated that the inhibition of NF- $\kappa \mathrm{B}$ activation might counteract the TNF- $\alpha$ effect. Among
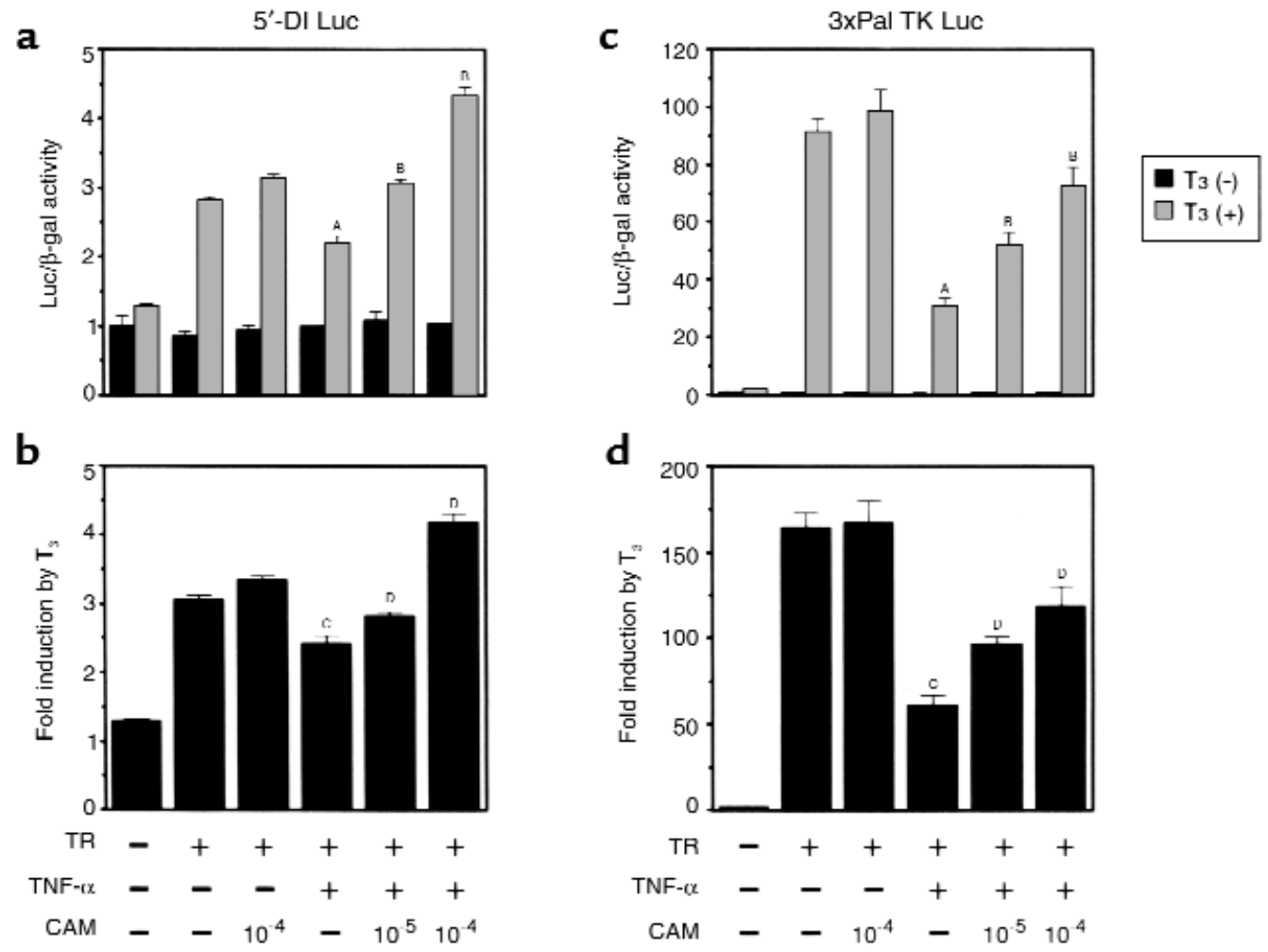

Figure 8

CAM counteracts the inhibition of $\mathrm{T}_{3}$-responsive luciferase reporter-gene ( $5^{\prime}$-DI Luc and $3 \times$ Pal TK Luc) expression by TNF- $\alpha$. (a and $\left.\mathbf{b}\right) \mathrm{T}_{3}{ }^{-}$ dependent induction of 5'-DI Luc activity was repressed by TNF- $\alpha$. However, the simultaneous treatment with CAM reversed this inhibitory effect in a dose-dependent manner. (c and $\mathbf{d}$ ) As observed with $5^{\prime}$-DI Luc, the inhibition of $\mathrm{T}_{3}$-dependent induction of $3 \times \mathrm{xPa}$ TK Luc by TNF- $\alpha$ was reversed in the presence of CAM. (a and $\mathbf{c})$ Luc/ $\beta$-gal activity. ${ }^{A} P<0.0001, T R(+), T_{3}(+)$ vs. TR $(+), T_{3}(+)$, TNF- $\alpha(+)$; ${ }^{B} P<0.0001$ vs. TR $(+), T_{3}(+)$, TNF- $\alpha(+)$. (b and d) Fold induction by $T_{3} .{ }^{C} P<0.0001$, TR vs. TR, TNF- $\alpha(+)$, D $P<0.0001$ vs. TR, TNF- $\alpha(+)$. 
a

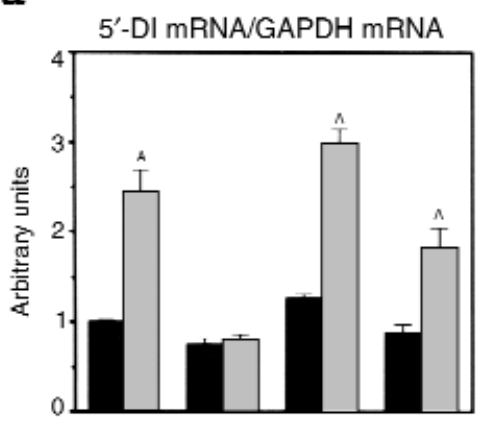

b

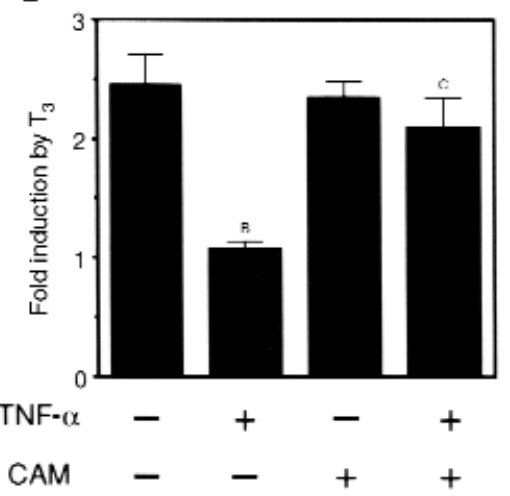

c

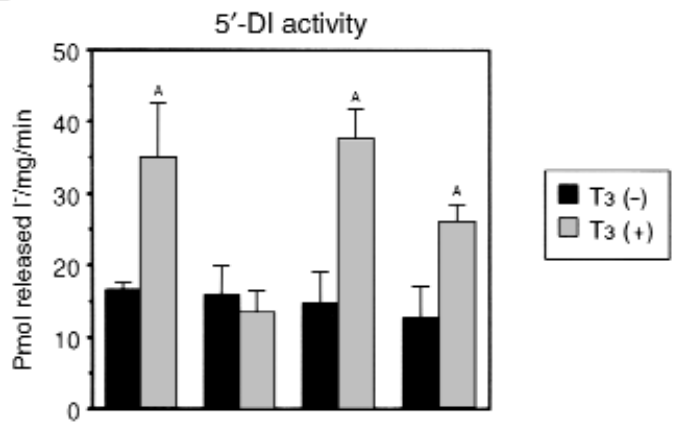

d

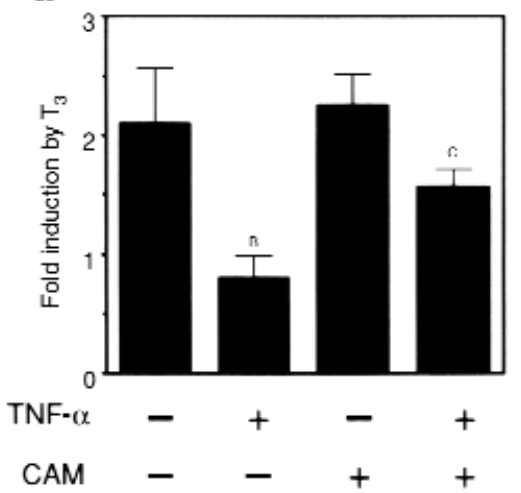

Figure 9

CAM restores the impaired $T_{3}$-dependent induction of $5^{\prime}-\mathrm{DI}$ expression by TNF- $\alpha$. (a and $\left.\mathbf{b}\right)$ The presence of CAM prevented the effect of TNF- $\alpha$ on $T_{3}$-dependent increase in 5'-DI mRNA. (a) The levels of 5'-DI/GAPDH mRNA expressed as mean \pm SD. (b) Fold induction of 5'DI/GAPDH mRNA by $T_{3}$. (c and d) The presence of CAM prevented the effect of TNF- $\alpha$ on $T_{3}$-dependent increase in $5^{\prime}$-DI activity. (c) The $5^{\prime}$-DI activity expressed as mean $\pm \mathrm{SD}(n=6)$. (d) Fold induction of $5^{\prime}$-DI enzyme activity by $T_{3}$. ${ }^{A} P<0.0001 \mathrm{vs}$. $T_{3}(-)$ in a and c; ${ }^{B} P<0.0001$, TNF- $\alpha(-)$, CAM (-) vs. TNF- $\alpha(+)$, CAM (-); ${ }^{C} P<0.001$, TNF- $\alpha(+)$ vs. TNF- $\alpha(+)$, CAM $(+)$ in $\mathbf{b}$ and $\mathbf{d}$.

various compounds that are clinically used, we found that one of the macrolide antibiotics, CAM, was reported to suppress the expression of proinflammatory cytokines such as IL-6 (41), IL-1 $\beta$, and IL-8 (42), which are known to be upregulated by NF- $\kappa B$. Thus, we tested whether CAM inhibits NF- $\mathrm{KB}$ activation by TNF- $\alpha$ in HepG 2 cells. The maximum concentration of CAM $\left(10^{-4} \mathrm{M}\right)$ used in the experiments was selected on the basis of tissue concentration when CAM is used clinically (described in detail in Methods).

Using EMSA, the induction of NF- $\mathrm{KB} 1$ hour after treatment with TNF- $\alpha$ was decreased by preincubation with CAM for 1 hour in a dose-dependent manner (Figure 7a). In support of this finding, the increase in NF-KB pGL3pro Luc activity by TNF- $\alpha$ was inhibited by the simultaneous administration of CAM (Figure 7, b and c), whereas the basal activity of pGL3pro Luc was not repressed by CAM (data not shown). These results indicate that CAM is an effective inhibitor of NF- $\mathrm{KB}$ activation.

The effect of CAM on NF-kB-dependent inhibition of TR action was studied using the transient transfection assay in HepG2 cells. In this system, under the conditions where the TNF- $\alpha$ effect was maximal on inhibiting the $\mathrm{T}_{3}$-dependent activation of $5^{\prime}$-DI Luc or $3 \times \mathrm{Pal}$ TK Luc, CAM was able to block the inhibitory effect of TNF- $\alpha$ (Figure 8 , a and $b$ ). The effects of CAM on the basal activity of 5'-DI Luc or 3xPal TK Luc were minimal.

We next asked whether CAM can counteract the effect of TNF- $\alpha$ on endogenous $5^{\prime}$-DI expression. As is shown in Figure 9 , a and b, TNF- $\alpha$ impairs the $T_{3}$-dependent activation of 5'-DI mRNA expression, and CAM itself does not influence the basal expression levels of 5'-DI mRNA. The presence of CAM abrogated the inhibitory action of TNF$\alpha$. Furthermore, the assessment of 5'-DI enzyme activity (Figure 9, c and d) supports the results of the Northern blot analysis, in that inhibition of $\mathrm{T}_{3}$-dependent increase in $5^{\prime}$ DI enzyme activity by TNF- $\alpha$ was blocked by the presence of CAM. These results indicate that CAM prevents the inhibitory action of TNF- $\alpha$ on the $T_{3}$-dependent increase in $5^{\prime}$-DI mRNA and enzyme activity.

\section{Discussion}

The present study demonstrates that activation of NF$\kappa B$ by TNF- $\alpha$ inhibits $T_{3}$-dependent induction of the $5^{\prime}$ DI gene in HepG2 cells. These data suggest a possible molecular basis of euthyroid sick syndrome, where the underlying disorder is associated with the increased level of circulating TNF- $\alpha$. Furthermore, our data suggest that inhibition of $\mathrm{T}_{3}$-dependent induction of $\mathrm{T}_{3}$-responsive genes by activated NF- $\mathrm{KB}$ is not restricted to $5^{\prime}$-DI 
gene, but is exerted on positively regulated $\mathrm{T}_{3}$-responsive genes. This inhibition is due to the interference with TR action by activated NF- $\mathrm{\kappa B}$, although we could find no evidence of direct association using EMSAs with TRELap and two-hybrid systems. However, we cannot exclude a possible interaction on other TREs or in the context of the native deiodinase promoter. In contrast to the positively regulated $T_{3}$-responsive genes, activated $\mathrm{NF}-\mathrm{KB}$ did not affect $\mathrm{T}_{3}$-dependent downregulation of the TSH- $\alpha$ reporter gene. Further in vivo studies are required to demonstrate the absence of a TNF- $\alpha$ effect on $\mathrm{T}_{3}$-mediated suppression of TSH expression.

Further evidence supporting this mechanism was obtained by using the macrolide antibiotic CAM. CAM, which blocks the activation of NF- $\mathrm{\kappa B}$ by TNF- $\alpha$, was able to prevent the effects of TNF- $\alpha$ on $5^{\prime}$-DI expression. Indeed, these results suggest that potentially CAM could be therapeutic in euthyroid sick syndrome.

The functional cross-talk between nuclear receptors and NF- $\kappa B$ has been reported for various classes of receptors. Activated NF- $\kappa B$ impairs the function of glucocorticoid receptor (GR), androgen receptor (AR), progesterone receptor (PR), and estrogen receptor (ER), as shown in several in vitro studies (43-46). Conversely, these receptors inhibit the action of NF- $\mathrm{KB}$ in the presence of their cognate ligands (46). The inhibitory effect of nuclear receptors on NF- $\kappa B$ bears relevance to a number of clinical situations. For example, dexamethasone is a potent immunosuppressor, and its action is mediated through the inhibition of NF- $\mathrm{KB}$ activation (47). Estrogen, which is used for the treatment of osteoporosis, is able to inhibit NF-KB-dependent induction of IL- 6 gene expression (48). The bidirectional cross-talk between NF- $\mathrm{KB}$ and classic steroid hormone receptors resembles the cross-talk between AP-1 and the nuclear receptors (49). However, the cross-talk between NF- $\mathrm{KB}$ and other classes of nuclear receptors may be distinct. As is shown in this study, NF- $\mathrm{KB}$ inhibited TR action, but liganded TR was reported not to inhibit NF- $\kappa B$ action (43). Unlike the TR, classic NRs such as the GR, PR, and ER interact directly with NF- $\mathrm{KB}$ through the second zinc finger. Differences in amino acid sequence may explain why the TR cannot directly interact with NF- $\mathrm{KB}(50)$. Thus, GR, ER, and PR interact directly with NF- $\kappa B$ and interfere with NF- $\kappa B$ signaling. In addition, NF- $\kappa B$ interferes with GR, PR, and ER action. However, the function of the TR, which does not physically associate with NF- $\kappa B$, is inhibited by $\mathrm{NF}-\kappa \mathrm{B}$, whereas NF- $\mathrm{\kappa B}$ function is not inhibited by the TR. It is assumed that the relative affinity to common factor may determine the direction of their mutual interactions. One possible mechanism for the inhibition of TR action by NF- $\mathrm{KB}$ is sequestration of the common cofactors shared between NF- $\kappa B$ and TR. CBP/p300 may be one of the candidates because it associates with both NF- KB (51) and nuclear receptors (52). However, cotransfection experiments using CBP-expression plasmid did not counteract the inhibitory action of NF- $\mathrm{KB}$ on $\mathrm{T}_{3^{-}}$ dependent transcription (data not shown). Other common factors between TR and NF- $\mathrm{KB}$ signaling, including IKBs and basal transcription factors, might be involved in the inhibition seen here.

The present study demonstrates that activated NF- $\kappa B$ is the potential molecular factor at the root of euthyroid sick syndrome in patients with increased circulating level of TNF- $\alpha$. This study also suggests that the inhibition of NF- $\mathrm{KB}$ may be a therapeutic target for the treatment of this syndrome. The potential applicability of CAM for the treatment of euthyroid sick syndrome could be supported by the following observation. CAM treatment extended the survival of patients with nonsmall-cell lung cancer (53). It has also been demonstrated that administration of CAM decreased the levels of IL-6, IL1 $\beta$, IL-8, and GM-CSF in synovial fibroblasts or bronchial epithelial cells $(41,42)$. The effect of CAM administration may be explained by the inhibition of NF- $\kappa B$ activation as demonstrated in this study. Although our in vitro findings cannot be fully extrapolated to clinical scenarios, the finding that CAM counteracts the inhibitory effect of TNF- $\alpha$ on $T_{3^{-}}$ dependent induction of $5^{\prime}$-DI and thereby maintains physiological concentration of $\mathrm{T}_{3}$ may provide one explanation for the improvement of cancer-associated cachexia by CAM therapy.

\section{Acknowledgments}

We thank R.M. Evans for the provision of TR $\beta$ and RXR $\alpha$ cDNAs, R.H. Goodman for CBP-expression plasmid, M. Murakami and N. Toyoda for technical advice regarding 5'-DI enzyme assays, and D. Sarkar and A.N. Hollenberg for their critical review of this manuscript. This work was supported in part by the grants from the Ministry of Education, Science and Culture, and the Ministry of Health and Welfare, Japan.

1. Toyoda, N., Zavacki, A.M., Maia, A.L., Harney, J.W., and Larsen, P.R. 1995. A novel retinoid $X$ receptor-independent thyroid hormone response element is present in the human type 1 deiodinase gene. Mol. Cell. Biol. 15:5100-5112.

2. Chopra, I.J. 1997. Clinical review 86: Euthyroid sick syndrome: is it a misnomer? J. Clin. Endocrinol. Metab. 82:329-334.

3. McIver, B., and Gorman, C.A. 1997. Euthyroid sick syndrome: an overview. Thyroid. 7:125-132.

4. De Groot, L.J. 1999. Dangerous dogmas in medicine: the nonthyroidal illness syndrome. J. Clin. Endocrinol. Metab. 84:151-164.

5. Maldonado, L.S., Murata, G.H., Hershman, J.M., and Braunstein, G.D. 1992. Do thyroid function tests independently predict survival in the critically ill? Thyroid. 2:119-123.

6. Opasich, C., et al. 1996. Sick euthyroid syndrome in patients with moderate-to-severe chronic heart failure. Eur. Heart J. 17:1860-1866.

7. Slag, M.F., et al. 1981. Hypothyroxinemia in critically ill patients as a predictor of high mortality. JAMA. 245:43-45.

8. Kaptein, E.M., Robinson, W.J., Grieb, D.A., and Nicoloff, J.T. 1982. Peripheral serum thyroxine, triiodothyronine and reverse triiodothyronine kinetics in the low thyroxine state of acute nonthyroidal illnesses. A noncompartmental analysis. J. Clin. Invest. 69:526-535.

9. Kaptein, E.M., Grieb, D.A., Spencer, C.A., Wheeler, W.S., and Nicoloff, J.T. 1981. Thyroxine metabolism in the low thyroxine state of critical nonthyroidal illnesses. J. Clin. Endocrinol. Metab. 53:764-771.

10. Blake, N.G., Eckland, D.J., Foster, O.J., and Lightman, S.L. 1991. Inhibition of hypothalamic thyrotropin-releasing hormone messenger ribonu- 
cleic acid during food deprivation. Endocrinology. 129:2714-2718.

11. Santini, F., and Chopra, I.J. 1992. A radioimmunoassay of rat type I iodothyronine 5'-monodeiodinase. Endocrinology. 131:2521-2526.

12. Boelen, A., Platvoet-ter Schiphorst, M.C., Bakker, O., and Wiersinga, W.M. 1995. The role of cytokines in the lipopolysaccharide-induced sick euthyroid syndrome in mice. J. Endocrinol. 146:475-483.

13. Boelen, A., Platvoet-ter Schiphorst, M.C., and Wiersinga, W.M. 1997. Immunoneutralization of interleukin-1, tumor necrosis factor, interleukin- 6 or interferon does not prevent the LPS-induced sick euthyroid syndrome in mice. J. Endocrinol. 153:115-122.

14. Chopra, I.J., Sakane, S., and Teco, G.N. 1991. A study of the serum concentration of tumor necrosis factor-alpha in thyroidal and nonthyroidal illnesses. J. Clin. Endocrinol. Metab. 72:1113-1116.

15. van der Poll, T., Endert, E., Coyle, S.M., Agosti, J.M., and Lowry, S.F. 1999. Neutralization of TNF does not influence endotoxin-induced changes in thyroid hormone metabolism in humans. Am. J. Physiol. 276:R357-R362.

16. van der Poll, T., Romijn, J.A., Wiersinga, W.M., and Sauerwein, H.P. 1990 Tumor necrosis factor: a putative mediator of the sick euthyroid syndrome in man. J. Clin. Endocrinol. Metab. 71:1567-1572.

17. Mooradian, A.D., Reed, R.L., Osterweil, D., Schiffman, R., and Scuderi, P. 1990. Decreased serum triiodothyronine is associated with increased concentrations of tumor necrosis factor. J. Clin. Endocrinol. Metab. 71:1239-1242.

18. Pang, X.P., Hershman, J.M., Mirell, C.J., and Pekary, A.E. 1989. Impairment of hypothalamic-pituitary-thyroid function in rats treated with human recombinant tumor necrosis factor-alpha (cachectin). Endocrinology. 125:76-84.

19. Verma, I.M., Stevenson, J.K., Schwarz, E.M., Van, A.D., and Miyamoto, S. 1995. Rel/NF-kappa B/I kappa B family: intimate tales of association and dissociation. Genes Dev. 9:2723-2735.

20. Bohrer, H., et al. 1997. Role of NF-kappa B in the mortality of sepsis. J. Clin. Invest. 100:972-985.

21. Aden, D.P., Fogel, A., Plotkin, S., Damjanov, I., and Knowles, B.B. 1979. Controlled synthesis of HBsAg in a differentiated human liver carcinoma-derived cell line. Nature. 282:615-616.

22. Nagaya, T., Madison, L.D., and Jameson, J.L. 1992. Thyroid hormone receptor mutants that cause resistance to thyroid hormone. J. Biol. Chem. 267:13014-13019.

23. Hayashi, Y., Sunthornthepvarakul, T., and Refetoff, S. 1994. Mutations of $\mathrm{CPG}$ dinucleotides located in the triiodothyronine (T3)-binding domain of the thyroid hormone receptor (TR) beta gene that appears to be devoid of natural mutations may not be detected because they are unlikely to produce the clinical phenotype of resistance to thyroid hormone. J. Clin. Invest. 94:607-615.

24. Tozawa, K., Sakurada, S., Kohri, K., and Okamoto, T. 1995. Effects of antinuclear factor kappa $\mathrm{B}$ reagents in blocking adhesion of human cancer cells to vascular endothelial cells. Cancer Res. 55:4162-4167.

25. Kwok, R.P., et al. 1996. Control of cAMP-regulated enhancers by the viral transactivator Tax through CREB and the co-activator CBP. Nature. 380:642-646

26. Kikumori, T., et al. 1998. Activation of transcriptionally active nuclear factor-kappa B by tumor necrosis factor-alpha and its inhibition by antioxidants in rat thyroid FRTL-5 cells. Endocrinology. 139:1715-1722.

27. Otsuka, G., et al. 1999. Inhibition of nuclear factor-kappa B activation confers sensitivity to tumor necrosis factor-alpha by impairment of cell cycle progression in human glioma cells. Cancer Res. 59:4446-4452.

28. Mandel, S.J., et al. 1992. Cloning and in vitro expression of the human selenoprotein, type I iodothyronine deiodinase. J. Clin. Endocrinol. Metab. 75:1133-1139.

29. Nagaya, T., et al. 1998. Intracellular proteolytic cleavage of 9-cis-retinoic acid receptor a by cathepsin L-type protease is a potential mechanism for modulating thyroid hormone action. J. Biol. Chem. 273:33166-33173.

30. Yamaguchi, S., et al. 1999. Glucocorticoids increase retinoid-X receptor alpha (RXRalpha) expression and enhance thyroid hormone action in primary cultured rat hepatocytes. J. Mol. Endocrinol. 22:81-90.
31. Chomczynski, P., and Sacchi, N. 1987. Single-step method of RNA isolation by acid guanidine thiocyanate-phenol-chloroform extraction. Anal. Biochem. 162:156-159.

32. Miyashita, K., Murakami, M., Iriuchijima, T., Takeuchi, T., and Mori, M. 1995. Regulation of rat liver type 1 iodothyronine deiodinase mRNA levels by testosterone. Mol. Cell. Endocrinol. 115:161-167.

33. Sato, M., et al. 1996. Antioxidants inhibit tumor necrosis factor-alpha mediated stimulation of interleukin-8, monocyte chemoattractant protein-1, and collagenase expression in cultured human synovial cells. $J$. Rheumatol. 23:432-438

34. Nagaya, T., and Jameson, J.L. 1993. Thyroid hormone receptor dimerization is required for dominant negative inhibition by mutations that cause thyroid hormone resistance. J. Biol. Chem. 268:15766-15771.

35. Graham, F.L., and van der Eb, A.J. 1973. Transformation of rat cells by DNA of human adenovirus 5. Virology. 52:456-487.

36. deWet, J.R., Wood, K.V., DeLuca, M., Helinski, D.R., and Subramani, S. 1987. Firefly luciferase gene: structure and expression in mammalian cells. Mol. Cell. Biol. 7:725-737.

37. Mikasa, K., et al. 1992. Long-term chemotherapy using erythromycin (EM) for chronic lower airway infection: effectiveness of clarithromycin in EM ineffective cases. Kansenshogaku Zasshi. 66:1097-1104.

38. Suwa, T., Yoshida, H., Fukushima, K., and Nagate, T. 1988. Metabolic fate of TE-031 (A-56268): comparative pharmatokinetics of TE-031 and erythromycin stearate in rats and mice. Chemotherapy. 36(Suppl. 3):198-204

39. Lin, K., et al. 1997. The gene regulating activity of thyroid hormone nuclear receptors is modulated by cell-type specific factors. Biochem. Biophys. Res. Commun. 238:280-284.

40. Ota, Y., Mariash, A., Wagner, J.L., and Mariash, C.N. 1997. Cloning, expression and regulation of the human S14 gene. Mol. Cell. Endocrinol. 126:75-81.

41. Takizawa, H., et al. 1995. Erythromycin suppresses interleukin 6 expression by human bronchial epithelial cells: a potential mechanism of its anti-inflammatory action. Biochem. Biophys. Res. Commun. 210:781-786.

42. Matsuoka, N., et al. 1996. Inhibitory effect of clarithromycin on costimulatory molecule expression and cytokine production by synovial fibroblast-like cells. Clin. Exp. Immunol. 104:501-508.

43. Caldenhoven, E., et al. 1995. Negative cross-talk between RelA and the glucocorticoid receptor: a possible mechanism for the anti-inflammatory action of glucocorticoids. Mol. Endocrinol. 9:401-412.

44. Kalkhoven, E., Wissink, S., van der Saag, P.T., and van der Burg, B. 1996. Negative interaction between the RelA (p65) subunit of NF-kappa B and the progesterone receptor. J. Biol. Chem. 271:6217-6224.

45. Palvimo, J.J., et al. 1996. Mutual transcriptional interference between RelA and androgen receptor. J. Biol. Chem. 271:24151-24156.

46. McKay, L.I., and Cidlowski, J.A. 1998. Cross-talk between nuclear factor$\kappa \mathrm{B}$ and the steroid hormone receptors: Mechanisms of mutual antagonism. Mol. Endocrinol. 12:45-56.

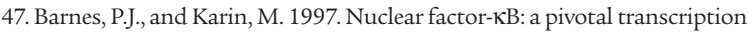
factor in chronic inflammatory diseases. N. Engl. J. Med. 336:1066-1071.

48. Stein, B, and Yang, M.X. 1995. Repression of the interleukin-6 promoter by estrogen receptor is mediated by NF-kappa B and C/EBP beta. Mol. Cell. Biol. 15:4971-4979.

49. Schule, R., et al. 1990. Functional antagonism between oncoprotein c-Jun and the glucocorticoid receptor. Cell. 62:1217-1226.

50. Liden, J., Delaunay, F., Rafter, I., Gustafsson, J., and Okret, S. 1997. A new function for the $\mathrm{C}$-terminal zinc finger of the glucocorticoid receptor. Repression of RelA transactivation. J. Biol. Chem. 272:21467-21472.

51. Perkins, N.D., et al. 1997. Regulation of NF-kappa B by cyclin-dependent kinases associated with the p300 coactivator. Science. 275:523-527.

52. Chakravarti, D., et al. 1996. Role of CBP/P300 in nuclear receptor signalling. Nature. 383:99-103.

53. Mikasa, K., et al. 1997. Significant survival benefit to patients with advanced non-small-cell lung cancer from treatment with clarithromycin. Chemotherapy. 43:288-296. 